\title{
Assessment of Iron Profile among Transfused Dependent Chronic Renal Failure Sudanese Patients
}

\author{
Moram Bder Aldein Abd Alla1, Khalid Mohamed Adam², Nasr Eldeen Ali Mohammed1* \\ ${ }^{1}$ Department of Hematology, Faculty of Medical Laboratory Sciences, Al-Neelain University, Khartoum, Sudan \\ ${ }^{2}$ Faculty of Applied Medical Sciences, Bisha University, Bisha, KSA \\ Email: "nasralimohammed@yahoo.com
}

Received 16 May 2016; accepted 28 August 2016; published 31 August 2016

Copyright (C) 2016 by authors and Scientific Research Publishing Inc.

This work is licensed under the Creative Commons Attribution International License (CC BY).

http://creativecommons.org/licenses/by/4.0/

(c) (i) Open Access

\begin{abstract}
Background: Anemia is one of the complications of chronic kidney disease (CKD) which necessitates multiple blood transfusions. These multiple transfusions are usually accompanied by Iron over load. The current study aimed to assess the Iron profile in Sudanese patients with chronic renal failure received regular blood transfused. Materials and Methods: A descriptive analytical case control study was performed in Alturki Teaching Hospital, Khartoum, Sudan. A total of 90 Sudanese were enrolled in this study (30 CKD patients under hemodialysis and undergo multiple blood transfusion, 30 CKD patients under hemodialysis but not blood transfusion and 30 healthy controls, 51 (57\%) were male and 39 (43\%) were females, their age ranged between 28 to 75 years. Iron profile (serum iron, serum ferritin and total iron binding capacity (TIBC)) were measured using full automated Chemical analyzer Mindray BS 200 (China). Data were analyzed by using statistical package for social sciences (SPSS) verssion16. Results: The present study showed that serum iron and serum ferritin of those under hemodialysis and received regular blood transfusion patient were significantly higher compared to those under hemodialysis and did not received regular blood transfusion patients ( $\mathrm{P}$ value 0.000 and 0.01$)$ respectively. Conclusion: Patients with chronic renal failure and under hemodialysis and receive regular and multiple transfusions are prone to iron overload.
\end{abstract}

\section{Keywords}

Iron Profile, Serum Iron, Serum Ferritin, Total Iron Binding Capacity, CKD

\section{Introduction}

Anemia commonly occurs in people with chronic kidney disease (CKD) — the permanent, partial losses of kid"Corresponding author.

How to cite this paper: Alla, M.B.A.A., Adam, K.M. and Mohammed, N.E.A. (2016) Assessment of Iron Profile among Transfused Dependent Chronic Renal Failure Sudanese Patients. Journal of Biosciences and Medicines, 4, 52-56. 
ney function. Anemia might begin to develop in the early stages of CKD, when someone has 20 to 50 percent of normal kidney function. Anemia tends to worsen as CKD progresses. Most people, who have total loss of kidney function, or kidney failure, have anemia [1].

Iron stores in normal subjects vary between approximately $800 \mathrm{mg}$ to $1200 \mathrm{mg}$, depending on body size [2], although phlebotomy studies suggest that normal iron stores may be as high as 1200 to $1500 \mathrm{mg}$ [3].

Ferritin is a protein found inside cells that stores iron so your body can use it later. A ferritin test indirectly measures the amount of iron in your blood. The amount of ferritin in your blood (serum ferritin level) is directly related to the amount of iron stored in your body [3].

Iron-binding capacity is usually measured by adding an excess of iron and measuring the iron retained in solution after the addition of a suitable reagent such as "light" magnesium carbonate or an ion-exchange resin that removes excess iron [4].

In dialysis patients because of the persistent anemia, Red blood cells (RBC) transfusions were often necessary and recombinant human erythropoietin (rHuEPO) therapy [5]. Regular blood transfusion and (rHuEPO) therapy lead to iron over load, Iron deposition in reticular endothelial system (RES) (gray-colored or bronze-colored skin, shortness of breath, arthritis, liver disease including cirrhosis or liver cancer and enlarged spleen) [6].

Primary iron overload, or primary hemochromatosis, is a common hereditary disorder in which excessive amounts of iron are absorbed from the gastrointestinal tract, resulting over many years in the accumulation of massive amounts of iron (as much as 20 to $40 \mathrm{~g}$ ) in the parenchymal cells of various tissues, leading to end-organ damage to the heart, liver, and pancreas [7].

The aim of this study was to assess the iron profile among Sudanese renal failure patients undergoing regular blood transfusion.

\section{Material and Method}

A descriptive analytical case control study carried out at faculty of Medical Laboratory Science, Alneelain University, with a sample comprised of 90 Sudanese participants, recruited from Alturki Teaching Hospital, Khartoum, Sudan. Assigned to three groups as follow, the first group included (30) hemodialyzed patients received multiple blood transfusions, $53 \%$ male and $47 \%$ female with mean age 55.2 years. The second group included (30) hemodialyzed patients did not receive multiple blood transfusions, $53 \%$ male and $47 \%$ female with mean age 56 years, and the third group included (30) healthy individuals as control group, 50\% male and 50\% female with mean age 55.4 years. Patients with liver disease, active infection and taking iron supplements were excluded. Blood specimens were taken from each participant, normal health control, patient known CRF treated regular blood transfused and others those without blood transfused $2.5 \mathrm{ml}$ of venous blood was collected in plain container. The clotted blood samples then centrifuged and the sera transferred to new containers. Chemical method were used to measure iron profile (serum iron, serum ferritin and TIBC) using full automated Chemical analyzer mindray BS 200 (China) using Iron-FZ Kit (SPINREACT-Spain) as per the manufacturer instructions. Data were analyzed by using statistical package for social sciences (SPSS) version 16. T. test and ANOVA test were used from comparison between different study groups, while the relations between groups were assessed with Pearson's correlation. The level of statistical significance was set at less than 0.05 .

\section{Result}

The results of the present study showed that the serum iron and serum ferritin of the patients under dialysis and regular red blood transfusion were significantly higher as compared to those under dialysis but not regular blood transfusion (P value 0.000 and 0.01 ) respectively as shown in Table 1.

While the total iron binding capacity in the dialyzed and regular blood transfusion was significantly lower as compared to the dialyzed did not received regular blood transfusion (P value 0.00) as shown in Table 1.

On the other hand the comparison of the study parameters between the patients groups and the control group revealed that the group of patients under dialysis and regular blood transfusion had a significantly higher serum iron and serum ferritin and no difference in terms of total iron binding capacity as compared to the control group with $P$ values $(0.000,0.000$, and 0.769$)$ respectively.

While the group of patients under dialysis but not regular blood transfusion had a significantly lower serum iron and serum ferritin and higher total iron binding capacity as compared to the control group with $\mathrm{P}$ value $(0.000)$ as shown in Table 1. 
The results of correlation of the study parameters and the age of the patient showed no statistically significant correlation between age of the patient and neither serum iron, nor serum ferritin, nor total iron binding capacity, with $P$ value $(0.398,0.197,0.094)$ respectively as shown in Table 2.

While the correlation results between the study parameters and the number of bag received by the patients showed a significantly strong positive correlation with serum iron, (P value 0.000$)$, and moderately positive correlation with serum ferritin, (P value 0.015 ), and a significantly strong converse relation with total iron binding capacity ( $\mathrm{P}$ value 0.000 ), as shown in Table 3 .

The different study parameters were compared based on the gender of the participant, and it was found that females had significantly higher serum iron $(151.15 \pm 147.32)$ as compared to males $(97.44 \pm 79.17)$ with (P value 0.029). For serum ferritin, females (64.90 \pm 14.68$)$ also showed significantly higher levels as compared to that of males (34.02 \pm 27.71 ) with (P value 0.008 ). While the level of total iron binding capacity showed no statistically

Table 1. ANOVA test for comparison of study parameters in different study groups.

\begin{tabular}{|c|c|c|c|c|}
\hline Parameter & & ups & Mean difference & $P$ value \\
\hline \multirow{3}{*}{ Serum iron } & \multirow{2}{*}{ Control } & Dialysis \& transfusion & -168.36 & 0.000 \\
\hline & & Dialysis \& no transfusion & 60.10 & 0.001 \\
\hline & Dialysis \& transfusion & Dialysis \& no transfusion & 228.47 & 0.000 \\
\hline \multirow{3}{*}{ Serum ferritin } & \multirow{2}{*}{ Control } & Dialysis \& transfusion & -67.85 & 0.000 \\
\hline & & Dialysis \& no transfusion & 23.69 & 0.068 \\
\hline & Dialysis \& transfusion & Dialysis \& no transfusion & 94.54 & 0.000 \\
\hline \multirow{3}{*}{ TIBC } & \multirow{2}{*}{ Control } & Dialysis \& transfusion & 125.10 & 0.769 \\
\hline & & Dialysis \& no transfusion & -907.07 & 0.000 \\
\hline & Dialysis \& transfusion & Dialysis \& no transfusion & -1032.17 & 0.000 \\
\hline
\end{tabular}

Table 2. Correlation between study parameters and age of the patient.

\begin{tabular}{ccc}
\hline Parameters & Correlation coefficient & Age \\
\hline Serum iron & Pearson correlation & 0.090 \\
& P value & 0.398 \\
Serum ferritin & Pearson correlation & 0.137 \\
& P value & 0.197 \\
TIBC & Pearson correlation & 0.178 \\
& P value & 0.094 \\
\hline
\end{tabular}

Table 3. Correlation between study parameters and No. of blood bags received.

\begin{tabular}{ccc}
\hline Parameters & Correlation coefficient & No. of bags \\
Serum iron & Pearson correlation & 0.884 \\
& P value & 0.000 \\
Serum ferritin & Pearson correlation & 0.441 \\
TIBC & Pealue & 0.015 \\
& P value & 0.814 \\
\hline
\end{tabular}


significant difference between females $(536.53 \pm 675.98)$ and males $(358.36 \pm 541.05)$ with $(\mathrm{P}$ value 0.169$)$ as shown in Table 4.

\section{Discussion}

Chronic kidney disease (CKD) is an irreversible progressive reduction in renal function an important source of long term morbidity and mortality. It has been estimated that CKD effect more than 20 million people in the united estate [8].

Anemia commonly occurs in people with CKD, when kidneys are damaged, they do not make enough EPO as a result the bone marrow makes fewer red cells, causing anemia. Other causes of anemia in CKD in include blood loss from steps of hemodialysis [9], to prevent of anemia to need frequent red blood cell transfusion and EPO therapy, due to blood transfused and EPO therapy to lead of iron over load [10].

This study was carried out in Alturki Teaching Hospital, Khartoum, Sudan. And aimed to assess the iron profile among transfused dependent end stag chronic renal failure in Sudanese patients, its included 60 subject known diagnosed with chronic renal failure (30 Dialyzed transfused blood, 30 dialyzed without blood transfused) compared with 30 normal health individual as control group.

The present study revealed that the iron profile (serum iron, serum ferritin and TIBC) were statistically significant different in patient with chronic renal failure received blood transfused compared with those non blood transfused (p value 0.00, 0.01 and 0.00 ) respectively. This findings in concordance to recently three different studies in literature; First study in 1994 done by Joseph W. EschbacH et al., who studied 166 transfused hemodialysis patients and reported that the iron status was increase, second study done by Canavese C, Bergamo D, Ciccone G, et al. in 2004 who was estimate the iron profile in 40 transfused hemodialysis patients and reported that $30 \%$ of the patients were normal and $70 \%$ iron were over load. Third study by Leonard Kouegnigan Rermbian et al. in 2012 who studied 85 hemodialysis patients and reported that a correlation between number of blood transfusion and iron profile [10]-[12].

The analysis result of this study showed that a positive and significant correlation between the number of transfusion bags and serum iron (Spearman r: 0.88; p value 0.00) followed by week positive and significant correlation between the numbers of transfusion bags and serum ferritin levels (Spearman $r: 0.44 ; p$ value 0.01 ) although negative and significant correlation between number of transfusion bags and TIBC (Spearman $\mathrm{r}:-0.81$; $\mathrm{p}$ value 0.00 ) this findings was agree with Leonard Kouegnigan Rerambiah et al. who reported that in their study a positive correlation between the number of transfusion bags and serum iron as well as serum ferritin [12].

According to the patients gender and age this study found that their no statistical significant correlation between iron profile and patients gender and age.

The major limitations in the present study are the small sample size, and relatively short study period.

\section{Conclusions}

The results of the current study suggest that regular blood transfusion for renal failure patients under hemodialysis increases the level of serum iron and serum ferritin and decreases total binding capacity, and these changes are not influenced by the age of the patient. These changes are more prominent when the number of blood bag received is considered.

Table 4. Comparison of study parameters according to gender of the participant.

\begin{tabular}{ccccc}
\hline Parameter & Gender & N & Mean & Std. deviation \\
Serum iron & Male & 51 & 97.44 & 79.17 \\
& Female & 39 & 151.15 & 147.32 \\
Serum ferritin & Male & 51 & 34.02 & 27.71 \\
& Female & 39 & 64.90 & 14.68 \\
TIBC & Male & 51 & 536.53 & 675.98 \\
& Female & 39 & 358.36 & 541.05
\end{tabular}


It can also be concluded that serum iron and serum ferritin differ based on the gender of the person but not the total binding capacity.

\section{References}

[1] Anemia in CKD.

https://www.niddk.nih.gov/health-information/health-topics/kidney-disease/anemia-in-kidney-disease-and-dialysis/Pag es/facts.aspx

[2] (1968) Council on Food, Nutrition Committee on Iron Deficiency: Iron Deficiency in the United States. JAMA, 203, 119-124.

[3] Haskins, D., Stevens, A.R. and Finchs, S.A. (1952) Iron Metabolism: Iron Stores in Man and Measured by Phlebotomy. Journal of Clinical Investigation, 31, 543-547. http://dx.doi.org/10.1172/JCI102639

[4] Daice and Lewis (2011) Practical Hematology: Estimation of Total Iron Binding Capacity. 11th Edition, 187.

[5] Stivelman, J., Schulman, G., Fosburg, M., Lazarus, J.M. and Hakim, R.M. (1989) Kinetics and Efficacy of Deferoxamine in Iron-Overloaded Hemodialysis Patients. Kidney International, 36, 1125-1132. http://dx.doi.org/10.1038/ki.1989.311

[6] McCarthy, J.T., Johnson, W.J., Nixon, D.E., Jenson, B.M. and Moyer, T.P. (1989) Transfusional Iron Overload in Patients Undergoing Dialysis: Treatment with Erythropoietin and Phlebotomy. Journal of Laboratory and Clinical Medicine, 114, 193-199.

[7] Finch, S.C. and Finch, C.A. (1955) Idiopathic Hemochromatosis, an Iron Storage Disease. Medicine, 34, 381-430. http://dx.doi.org/10.1097/00005792-195512000-00001

[8] National Kidney Foundation (2002) klDOQI Clinical Practice Guideline for Chronic Kidney Disease: Evaluation, Classification, and Stratification. American Journal of Kidney Diseases, 39, s1-s266.

[9] Brugnara, C. and Eckardt, K.U. (2011) Hematologic Aspects of Kidney Disease. In: Taal, M.W., Ed., Brenner and Rector's the Kidney, 9th Edition, Saunders, Philadelphia, 2081-2120.

[10] Eschbach, J.W. and Adamason, J.W. (1994) Iron over Load in Renal Failure. New York Blood Center, 515.

[11] Canavese, C., Bergamo, D., Ciccone, G., et al. (2004) Harmful Iron over Load in Dialysis Patients. Kidney International, 65, 1091-1098.

[12] Kouegnigan Rerambiah, L., Essola Rerambiah, L., Mbourou Etomba, A., Mouguiama, R.M., Issanga, P.B., Biyoghe, A.S., Batchilili, B., Akone Assembe, S. and Djoba Siawaya, J.F. (2015) Blood Transfusion, Serum Ferritin, and Iron in Hemodialysis Patients in Afric. Journal of Blood Transfusion, 720389.

\section{Submit or recommend next manuscript to SCIRP and we will provide best service for you:}

Accepting pre-submission inquiries through Email, Facebook, LinkedIn, Twitter, etc.

A wide selection of journals (inclusive of 9 subjects, more than 200 journals)

Providing 24-hour high-quality service

User-friendly online submission system

Fair and swift peer-review system

Efficient typesetting and proofreading procedure

Display of the result of downloads and visits, as well as the number of cited articles

Maximum dissemination of your research work

Submit your manuscript at: http://papersubmission.scirp.org/ 